\title{
Factors Associated With Early Mortality in Patients Treated With Concurrent Chemoradiation Therapy for Locally Advanced Non-Small Cell Lung Cancer
}

Citation for published version (APA):

Warner, A., Dahele, M., Hu, B., Palma, D. A., Senan, S., Oberije, C., Tsujino, K., Moreno-Jimenez, M., Kim, T. H., Marks, L. B., Rengan, R., De Petris, L., Ramella, S., De Ruyck, K., Rodriguez De Dios, N., Bradley, J. D., \& Rodrigues, G. (2016). Factors Associated With Early Mortality in Patients Treated With Concurrent Chemoradiation Therapy for Locally Advanced Non-Small Cell Lung Cancer. International Journal of Radiation Oncology Biology Physics, 94(3), 612-620.

https://doi.org/10.1016/j.jirobp.2015.11.030

Document status and date:

Published: 01/03/2016

DOI:

10.1016/j.ijrobp.2015.11.030

Document Version:

Publisher's PDF, also known as Version of record

Document license:

Taverne

Please check the document version of this publication:

- A submitted manuscript is the version of the article upon submission and before peer-review. There can be important differences between the submitted version and the official published version of record.

People interested in the research are advised to contact the author for the final version of the publication, or visit the DOI to the publisher's website.

- The final author version and the galley proof are versions of the publication after peer review.

- The final published version features the final layout of the paper including the volume, issue and page numbers.

Link to publication

\footnotetext{
General rights rights.

- You may freely distribute the URL identifying the publication in the public portal. please follow below link for the End User Agreement:

www.umlib.nl/taverne-license

Take down policy

If you believe that this document breaches copyright please contact us at:

repository@maastrichtuniversity.nl

providing details and we will investigate your claim.
}

Copyright and moral rights for the publications made accessible in the public portal are retained by the authors and/or other copyright owners and it is a condition of accessing publications that users recognise and abide by the legal requirements associated with these

- Users may download and print one copy of any publication from the public portal for the purpose of private study or research.

- You may not further distribute the material or use it for any profit-making activity or commercial gain

If the publication is distributed under the terms of Article $25 \mathrm{fa}$ of the Dutch Copyright Act, indicated by the "Taverne" license above, 


\title{
Factors Associated With Early Mortality in Patients Treated With Concurrent Chemoradiation Therapy for Locally Advanced Non-Small Cell Lung Cancer
}

\author{
Andrew Warner, MSc, ${ }^{*}$ Max Dahele, MBChB, PhD, FRCP, FRCR, \\ Bo Hu, MSc, * David A. Palma, MD, PhD, FRCPC, * \\ Suresh Senan, MRCP, FRCR, PhD, Cary Oberije, MSc, PhD ${ }^{\ddagger}$ \\ Kayoko Tsujino, MD, PhD, Marta Moreno-Jimenez, MD, PhD, \\ Tae Hyun Kim, MD, Lawrence B. Marks, MD," \\ Ramesh Rengan, MD, PhD, ** Luigi De Petris, MD, PhD, ${ }^{\dagger \dagger}$ \\ Sara Ramella, MD, Kim De Ruyck, PhD, $\$ \oint$ \\ Núria Rodriguez De Dios, MD, PhD, \|\| Jeffrey D. Bradley, MD, बबा \\ and George Rodrigues, MD, PhD, FRCPC*
}

*Department of Radiation Oncology, London Health Sciences Centre, London, Ontario, Canada; ${ }^{\dagger}$ Department of Radiation Oncology, VU University Medical Center, Amsterdam, The Netherlands; ${ }^{\ddagger}$ Department of Radiation Oncology, MAASTRO Clinic, Maastricht, The Netherlands; ${ }^{\S}$ Department of Radiation Oncology, Hyogo Cancer Center, Akashi, Japan; "Department of Oncology, Clínica Universidad, Universidad de Navarra, Pamplona, Spain; "Department of Radiation Oncology, National Cancer Center, Goyang-si, Gyeonggi, Korea; ${ }^{\#}$ Department of Radiation Oncology, University of North Carolina Chapel Hill, Chapel Hill, North Carolina; **Department of Radiation Oncology, University of Washington, Seattle, Washington; ${ }^{\dagger \dagger}$ Department of Oncology and Pathology, Karolinska University Hospital, Stockholm, Sweden; ${ }^{\ddagger}$ Department of Radiation Oncology, Campus Bio-Medico University, Rome, Italy; ${ }^{\S}$ Department of Basic Medical Sciences, Ghent University, Ghent, Belgium; "INepartment of Radiation Oncology, Hospital de la Esperanza, Parc de Salut Mar, Barcelona, Spain; and ${ }^{\top \uparrow}$ Department of Radiation Oncology, Washington University School of Medicine, St Louis, Missouri

Reprint requests to: $\mathrm{Dr}$ George Rodrigues, $\mathrm{MD}, \mathrm{PhD}$, FRCPC, Department of Radiation Oncology, London Health Sciences Centre, Rm A3-808, 790 Commissioners Rd East, London, Ontario N6A 4L6, Canada. Tel: (519) 685-8500 ext. 52833; E-mail: George.Rodrigues@1hsc.on.ca

This work was funded by Ontario Institute of Cancer Research grants (high-impact clinical trials) and National Institutes of Health award ca69579.
Conflict of interest: The Department of Radiation Oncology, VU University Medical Center has research collaborations with Varian Medical Systems, Brainlab AG, and Velocity Medical Solutions. M.D. has received travel support and honoraria from Varian Medical Systems, Brainlab AG, and Lilly. S.S. has received travel support and honoraria from Varian Medical Systems. 


\section{Summary}

The current study identified performance status, total radiation dose, and gross tumor volume (GTV) as significant univariate predictors of 180-day survival. Pulmonary function (forced expiratory volume in 1 second $\left[\mathrm{FEV}_{1}\right]$, defined as the ratio of $\mathrm{FEV}_{1}$ to forced vital capacity [FVC]) emerged as the dominant multivariate predictor of 180-day survival after adjusting for $\mathrm{N}$ stage, tumor volume, and maximum esophagus dose. A 2-class prognostic recursive partitioning analysis risk stratification system based on poor pulmonary function $\left(\mathrm{FEV}_{1}<80 \%\right)$ in conjunction with larger tumor volumes $\left(\mathrm{GTV} \geq 100 \mathrm{~cm}^{3}\right)$ predicted for worse prognosis at 180 days after radiation therapy.
Purpose: Concurrent chemoradiation therapy (con-CRT) is recommended for fit patients with locally advanced non-small cell lung cancer (LA-NSCLC) but is associated with toxicity, and observed survival continues to be limited. Identifying factors associated with early mortality could improve patient selection and identify strategies to improve prognosis.

Methods and Materials: Analysis of a multi-institutional LA-NSCLC database consisting of 1245 patients treated with con-CRT in 13 institutions was performed to identify factors predictive of 180-day survival. Recursive partitioning analysis (RPA) was performed to identify prognostic groups for 180-day survival. Multivariate logistic regression analysis was used to create a clinical nomogram predicting 180-day survival based on important predictors from RPA.

Results: Median follow-up was 43.5 months (95\% confidence interval [CI]: 40.348.8) and 127 patients (10\%) died within 180 days of treatment. Median, 180-day, and 1- to 5-year (by yearly increments) actuarial survival rates were 20.9 months, $90 \%, 71 \%, 45 \%, 32 \%, 27 \%$, and $22 \%$ respectively. Multivariate analysis adjusted by region identified gross tumor volume (GTV) (odds ratio $[\mathrm{OR}] \geq 100 \mathrm{~cm}^{3}: 2.61$; 95\% CI: $1.10-6.20 ; P=.029)$ and pulmonary function (forced expiratory volume in 1 second $\left[\mathrm{FEV}_{1}\right]$, defined as the ratio of $\mathrm{FEV}_{1}$ to forced vital capacity [FVC]) (OR $<80 \%$ : 2.53 ; $95 \%$ CI: $1.09-5.88 ; P=.030)$ as significant predictors of 180 -day survival. RPA resulted in a 2-class risk stratification system: low-risk (GTV $<100 \mathrm{~cm}^{3}$ or GTV $\geq 100 \mathrm{~cm}^{3}$ and $\mathrm{FEV}_{1} \geq 80 \%$ ) and high-risk (GTV $\geq 100 \mathrm{~cm}^{3}$ and $\mathrm{FEV}_{1}$ $<80 \%$ ). The 180 -day survival rates were $93 \%$ for low risk and $79 \%$ for high risk, with an OR of 4.43 (95\% CI: 2.07-9.51; $P<.001$ ), adjusted by region. A clinical nomogram predictive of 180-day survival, incorporating $\mathrm{FEV}_{1}$, GTV, $\mathrm{N}$ stage, and maximum esophagus dose yielded favorable calibration $\left(\mathrm{R}^{2}=0.947\right)$.

Conclusions: This analysis identified several risk factors associated with early mortality and suggests that future research in the optimization of pretreatment pulmonary function and/or functional lung avoidance treatment may alter the therapeutic ratio in this patient population. (C) 2016 Elsevier Inc. All rights reserved.

\section{Introduction}

Concurrent chemoradiation therapy (con-CRT) is guideline recommended as the preferred treatment for selected, fit patients with locally advanced non-small cell lung cancer (LA-NSCLC) $(1,2)$. It results in a typical median survival of approximately 18 to 28 months, at the cost of a treatment duration of approximately 6 to 8 weeks and a risk of esophageal and lung toxicity, both of which can result in a substantial symptom burden and incur additional healthcare costs (1-3). In some patients, toxicity is severe enough to be fatal (3). Although sequential chemoradiation therapy (seq-CRT) is a less toxic option, it fell out of favor after randomized clinical trials and a meta-analysis reported a survival advantage with con-CRT $(3,4)$. Nevertheless, lung cancer patient populations receiving con-CRT have been observed to have mortality rates as high as $20 \%$ and $40 \%$ at 6 and 12 months, respectively, in some cases (4).

Therefore, some patients treated using con-CRT are likely exposed to higher rates of toxicity for little benefit. If patients at high risk of early death could be identified before starting treatment, then they could potentially be offered less toxic and more individualized therapy. In addition, if factors associated with early death could be identified, then therapeutic strategies to minimize the chance of a patient developing these factors might represent opportunities to improve prognosis. Therefore, the primary aim of this retrospective analysis was to identify and organize (into risk stratification groups and a clinical nomogram) clinically relevant parameters associated with early mortality at 180 days after the application of con-CRT for patients with LA-NSCLC.

\section{Methods and Materials}

The current study was performed using a multiinstitutional, international collaborative database, created for the purpose of further understanding the relationships between clinical, tumor, and dosimetric predictive factors, development of radiation pneumonitis and radiation esophagitis, and survival outcomes (5-7). The individual patient retrospective database used for this study consists of data from 13 institutions $(n=1274)$. Institutional Research Ethics Board approval was obtained for this investigation. 
Patients were considered eligible if they were treated for stage III LA-NSCLC and received radical intent con-CRT using 3-dimensional (3D) conformal radiation therapy or intensity modulated radiation therapy with a biological effective dose (BED) calculated with an $\alpha / \beta$ ratio of 10 equivalent to $\geq 60$ Gy delivered in $\geq 25$ fractions. Neoadjuvant and/or adjuvant chemotherapy was allowed. Patients were excluded if they received surgical resection, had stage I to II or IV disease, small cell histology, were treated with palliative intent con-CRT, or were missing survival data.

Primary endpoint for this study was 180-day survival (death) defined as death occurring $\leq 180$ days from initiation of radiation therapy or censored if death occurred $>180$ days from initiation of radiation therapy. Patients were coded as missing if they were censored $<180$ days from initiation of radiation therapy and excluded from further analysis $(n=29)$, which resulted in 1245 patients remaining for final analysis. The secondary endpoint for this study was overall survival (OS), defined as time from initiation of radiation therapy to date of last follow-up and/ or death, whichever came first. Acute radiation esophagitis and radiation pneumonitis toxicity grading were scored according to either Common Terminology Criteria for Adverse Events (CTCAE, version 3 or 4) or Radiation Therapy and Oncology Group (RTOG) scale consistent with previous analyses $(5,6)$. The volume of lung considered as the organ at risk (OAR) was defined as the total lung volume minus the gross tumor volume (ie, "total lung-GTV"). For patients whose lung volume receiving $>=20$ Gy (V20) were available only by use of the definition of lung OAR as total lung minus planning target volume (ie, "total lung-PTV"), the corresponding "total lung-GTV" values were calculated by imputation based on a linear relationships between the 2 definitions, which was found to be a good fit, with $\mathrm{R}^{2}=0.988$. A total of 228 patients $(39 \%)$ were imputed using this method. GTV was defined as a composite volume incorporating both primary tumor GTV and nodal GTV.

\section{Statistical analysis}

Descriptive statistics were generated for baseline patient, tumor, and treatment characteristics for all patients $(\mathrm{n}=1245)$. Univariate logistic regression analysis was performed to identify significant $(P<.05)$ and nonsignificant $(P<30)$ predictors of 180-day survival (death), removing variables with no observed association with 180 day survival $(P>.30)$ from further consideration. Recursive partitioning analysis (RPA) was performed using the binary function (yes/no) for 180-day survival based on remaining eligible predictors $(P<.30)$. Variables were sequentially removed according to the R-based variable importance algorithm, which calculates a numerical value for each factor to indicate strength of risk partitioning ability. Default settings were used (minimum number of 20 observations in a node required to enable further splitting), followed by trimming of less important downstream branches as needed. Cutpoints were rounded to represent more clinically meaningful values. Kaplan-Meier estimates of OS were generated for all patients $(n=1245)$ and stratified by RPA risk group systems for 180-day survival, compared using the log-rank test.

Multivariate logistic regression analysis was performed based on important predictors identified from RPA and used to develop a clinical nomogram to calculate individual patient-level probability estimates for 180-day survival according to each patient's particular combination of baseline characteristics. Nomogram validation was performed by calibration plots of nomogram-predicted 180day survival probability compared to observed 180-day survival respectively, evaluated using the $\mathrm{R}^{2}$ statistic. Additionally, all reported odds ratios were adjusted by region. All statistical analysis was performed using SAS version 9.4 software (SAS institute, Cary, NC) and the R language environment for statistical computing version 3.1.3 (open source; www.r-project.org), using 2-sided statistical testing at the .05 significance level.

\section{Results}

Individual patient data were available for 1245 patients from 13 institutions, consisting of patients treated in Europe $(n=736[59 \%])$, North America $(n=206[17 \%])$, and Asia $(\mathrm{n}=226[18 \%])$ and from 1 multicenter study $(n=77[6 \%])$. Baseline patient characteristics are summarized in Table 1.

Patient deaths were observed in 844 of 1245 patients (68\%), with 127 (10\%) occurring within 180 days of start of radiation therapy. Acute radiation esophagitis (any grade) was reported in 761 patients (84\%), 158 (18\%) with grade 3 and $8(0.9 \%)$ with grade 4 . No esophagitis-related deaths were reported. Radiation pneumonitis was reported in 409 patients $(56 \%), 51(7 \%)$ with grade 3 and $4(0.5 \%)$ with grade 4. Thirteen pneumonitis-related deaths $(2 \%)$ were observed, 5 occurring within 180 days, 6 occurring between 180 days and 1 year, and 2 occurring $>1$ year from treatment. Median actuarial follow-up was 43.5 months (95\% confidence interval [CI]: 40.3-48.8 months). Median, 180-day, and 1-year to 5-year actuarial survival rates were 20.9 months, $90 \%$, $71 \%, 45 \%, 32 \%, 27 \%$, and $22 \%$ respectively (Fig. $1 \mathrm{~A}$ ).

Results from univariate logistic regression for 180-day survival adjusted by region (Table 2) identified poor performance status (odds ratio [OR] predicting death: 2.84; 95\% CI: $1.27-6.32 ; P=.011$ ), total radiation dose (OR per 5-Gy increase: $0.75 ; 95 \%$ CI: $0.63-0.90 ; P=.002)$ and GTV (OR: $\geq 100 \mathrm{~cm}^{3}, 2.53$; 95\% CI: $1.53-4.18 ; P<.001$ ) as significant predictors of 180-day survival. Multivariate analysis adjusted by region identified GTV (OR: $\geq 100 \mathrm{~cm}^{3}: 2.61 ; 95 \%$ CI: $\left.1.10-6.20 ; P=.029\right)$ and pulmonary function (forced expiratory volume in 1 second $\left[\mathrm{FEV}_{1}\right]$, defined as the ratio of $\mathrm{FEV}_{1}$ to forced vital capacity 
Table 1 Baseline tumor, patient, and treatment characteristics for all patients $(n=1245)$

\begin{tabular}{|c|c|c|}
\hline Characteristic & $\mathrm{N}$ & All Patients $(n=1245)$ \\
\hline Mean $\pm \mathrm{SD} /$ median (range) age (y) & 1243 & $62.14 \pm 9.07 / 62.92(32.00-84.58)$ \\
\hline No. of males $(\%)$ & 1067 & $787(73.8)$ \\
\hline \multicolumn{3}{|l|}{ No. of patients with stage shown (\%) } \\
\hline $3 \mathrm{a}$ & 1160 & $366(31.6)$ \\
\hline $3 b$ & & $650(56.0)$ \\
\hline 3 (not specified) & & $143(12.3)$ \\
\hline \multicolumn{3}{|l|}{ No. of patients with $\mathrm{T}$ stage shown $(\%)$} \\
\hline $\mathrm{T} 1$ & 1075 & $103(9.6)$ \\
\hline $\mathrm{T} 2$ & & $291(27.1)$ \\
\hline $\mathrm{T} 3$ & & $248(23.1)$ \\
\hline $\mathrm{T} 4$ & & $433(40.3)$ \\
\hline \multicolumn{3}{|l|}{ No. of patients with $\mathrm{N}$ stage shown $(\%)$} \\
\hline N0 & 1081 & $110(10.2)$ \\
\hline N1 & & $40(3.7)$ \\
\hline $\mathrm{N} 2$ & & $636(58.8)$ \\
\hline N3 & & $295(27.3)$ \\
\hline Mean $\pm \mathrm{SD} /$ median $(\min , \max )$ gross tumor volume $\left(\mathrm{cm}^{3}\right)$ & 745 & $135.18 \pm 145.78 / 85.07(1.68,1310.00)$ \\
\hline \multicolumn{3}{|l|}{ No. of patients with tumor lobe location as indicated (\%) } \\
\hline Lower & 771 & $179(23.2)$ \\
\hline Middle & & $47(6.1)$ \\
\hline Upper & & $545(70.7)$ \\
\hline \multicolumn{3}{|l|}{ No. of patients with histology type as indicated (\%) } \\
\hline Adenocarcinoma & 1245 & $289(23.2)$ \\
\hline Squamous & & $338(27.2)$ \\
\hline Large cell & & $145(11.7)$ \\
\hline Not otherwise specified & & $473(38.0)$ \\
\hline No. of current or former smokers $(\%)$ & 495 & $450(90.9)$ \\
\hline Mean $\pm \mathrm{SD} /$ median $(\min , \max ) \mathrm{FEV}_{1} \%$ & 532 & $79.34 \pm 19.61 / 79.50(25.00,141.00)$ \\
\hline No. of patients with good performance status $(\%)^{*}$ & 674 & $636(94.4)$ \\
\hline Median treatment year $(\min , \max )$ : & 688 & $2005(1995,2010)$ \\
\hline \multicolumn{3}{|l|}{ No. of patients within treatment year shown $(\%)$} \\
\hline $1995-1999$ & 688 & $100(14.5)$ \\
\hline $2000-2003$ & & $188(27.3)$ \\
\hline 2004-2007 & & $255(37.1)$ \\
\hline $2008-2010$ & & $145(21.1)$ \\
\hline \multicolumn{3}{|l|}{ Patients receiving concurrent chemotherapy (\%) } \\
\hline Platinum-based + etoposide & 1087 & $300(27.6)$ \\
\hline Platinum-based + taxane & & $322(29.6)$ \\
\hline Other platinum-based chemotherapy & & $133(12.2)$ \\
\hline Not otherwise specified & & $332(30.5)$ \\
\hline Mean $\pm \mathrm{SD} /$ median $(\min , \max )$ total radiation dose $(\mathrm{Gy})$ & 1245 & $\begin{array}{c}62.25 \pm 5.23 \\
60.00(50.00,82.60)\end{array}$ \\
\hline Median no. of fractions (min, $\max$ ): & 1245 & $33(25,68)$ \\
\hline Mean $\pm \mathrm{SD} /$ median $(\min , \max )$ dose per fraction $(\mathrm{Gy})$ & 1245 & $1.85 \pm 0.22 / 2.00(1.20,2.40)$ \\
\hline $\begin{array}{l}\text { Mean } \pm \mathrm{SD} / \text { median (min, max) esophagus maximum } \\
\text { dose }(\mathrm{Gy})\end{array}$ & 505 & $64.41 \pm 9.31 / 65.60(7.40,80.10)$ \\
\hline mean $\pm \mathrm{SD} /$ median $(\min , \max )$ lung V20 $(\%)$ & 582 & $\begin{array}{c}30.25 \pm 10.05 \\
29.58(10.00,71.58)\end{array}$ \\
\hline \multicolumn{3}{|l|}{ No. of patients with esophagitis grades shown (\%) } \\
\hline 0 & 902 & $141(15.6)$ \\
\hline 1 & & $196(21.7)$ \\
\hline 2 & & $399(44.2)$ \\
\hline 3 & & $158(17.5)$ \\
\hline 4 & & $8(0.9)$ \\
\hline
\end{tabular}


Table 1 (continued)

\begin{tabular}{|c|c|c|}
\hline Characteristic & $\mathrm{N}$ & All Patients $(n=1245)$ \\
\hline \multicolumn{3}{|l|}{ No. of patients with pneumonitis grade shown (\%) } \\
\hline 0 & 736 & $327(44.4)$ \\
\hline 1 & & $152(20.7)$ \\
\hline 2 & & $189(25.7)$ \\
\hline 3 & & $51(6.9)$ \\
\hline 4 & & $4(0.5)$ \\
\hline 5 & & $13(1.8)$ \\
\hline No. of patients who died $(\%)$ & 1245 & $844(67.8)$ \\
\hline No. of patients who reached 180 -day death $(\%)$ & 1245 & $127(10.2)$ \\
\hline Median follow-up (95\% CL) (months) ${ }^{\dagger}$ & 1245 & $43.50(40.31-48.76)$ \\
\hline
\end{tabular}

[FVC]) (OR: $<80 \%: 2.53 ; 95 \%$ CI: $1.09-5.88 ; P=.030)$ as significant predictors of 180-day survival when modeled according to RPA cutpoints. Pulmonary function (OR per $10 \%$ increase: 0.76 ; $95 \%$ CI: $0.58-1.00 ; P=.047$ ) remained the dominant predictor of 180-day survival after adjusting for region (not reported), $\mathrm{N}$ stage (overall $P=.261$ ), GTV
(OR per $50-\mathrm{cm}^{3}$ increase: 1.03 , 95\% CI: 0.90-1.18; $P=.698$ ), and maximum esophagus dose (OR per 5-Gy increase: $1.07 ; 95 \%$ CI: $0.75-1.52 ; P=.720 ; C$-index: 0.692). Performance status and total radiation dose were not found to be significant multivariate predictors of 180 day survival.
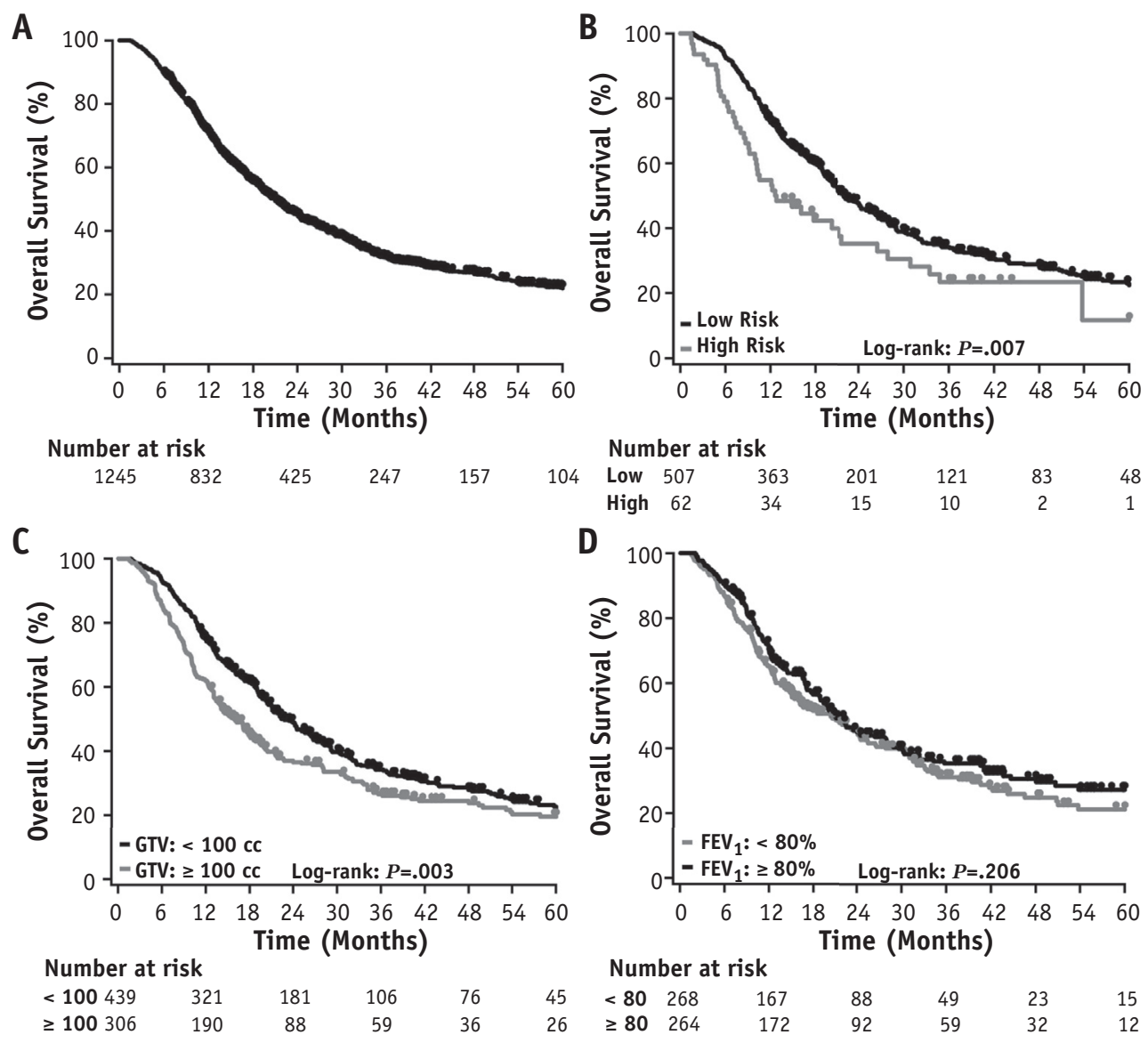

Number at risk

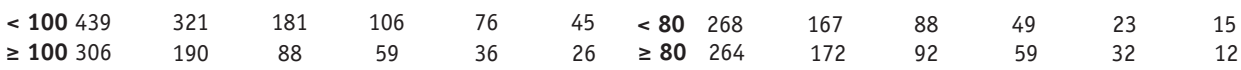

Fig. 1. (A-D) Kaplan-Meier plot for overall survival for $(A)$ all patients $(n=1245)$ and stratified by (B) 180-day survival RPA risk group system, (C) GTV, and (D) $\mathrm{FEV}_{1}$. Abbreviations: $\mathrm{FEV}_{1}=$ forced expiratory volume in 1 second (defined as the ratio of $\mathrm{FEV}_{1}$ to forced vital capacity $[\mathrm{FVC}]$ ); GTV = gross tumor volume; RPA = recursive partitioning analysis. 
Table 2 Univariate and multivariate logistic regression models predictive of 180-day survival $($ death $)(n=1245)^{*}$

\begin{tabular}{|c|c|c|c|c|c|c|c|c|c|c|c|c|}
\hline $\begin{array}{c}\text { Dependent variable: } \\
\text { 180-day survival (death) } \\
\text { Independent variables }\end{array}$ & \multicolumn{3}{|c|}{ Univariate model } & \multicolumn{3}{|c|}{$\begin{array}{l}\text { RPA multivariate } \\
\text { model } 1(\mathrm{C} \text {-index: } \\
0.646)\end{array}$} & \multicolumn{3}{|c|}{$\begin{array}{c}\text { RPA multivariate } \\
\text { model } 2 \text { (C-index: } \\
0.668)\end{array}$} & \multicolumn{3}{|c|}{$\begin{array}{l}\text { Nomogram multivariate } \\
\text { model (C-index: 0.692) }\end{array}$} \\
\hline $\mathrm{N}$ stage & & & .173 & & & - & & & - & & & .261 \\
\hline N1 vs N0 & 2.50 & $(0.89,6.75)$ & .083 & - & - & - & - & - & - & - & - & - \\
\hline N3 vs N0 (vsN0-N1)* & 1.20 & $(0.57,2.55)$ & .631 & - & - & - & - & - & - & $5.55^{*}$ & $(0.62,49.43)^{*}$ & $.125^{*}$ \\
\hline GTV per $50-\mathrm{cm}^{3}$ increase & 1.08 & $(1.00,1.17)$ & .053 & 1.04 & $\begin{array}{r}(0.93 \\
1.17)\end{array}$ & .475 & - & - & - & 1.03 & $(0.90,1.18)$ & .698 \\
\hline $\begin{array}{c}\text { GTV }(\text { RPA cutpoint }) \geq \\
100 \text { vs }<100 \mathrm{~cm}^{3}\end{array}$ & 2.53 & $(1.53,4.18)$ & $<.001$ & - & - & - & 2.61 & $\begin{array}{r}(1.10 \\
6.20)\end{array}$ & .029 & - & - & - \\
\hline $\mathrm{FEV}_{1}$ per $10 \%$ increase & 0.93 & $(0.81,1.07)$ & .296 & 0.79 & $\begin{array}{r}(0.64, \\
0.99)\end{array}$ & .040 & - & - & - & 0.76 & $(0.58,1.00)$ & .047 \\
\hline Histology & & & .318 & & & - & & & - & & & - \\
\hline $\begin{array}{l}\text { Squamous vs } \\
\text { adenocarcinoma }\end{array}$ & 1.06 & $(0.64,1.76)$ & .819 & - & - & - & - & - & - & - & - & - \\
\hline $\begin{array}{l}\text { Large cell vs } \\
\text { adenocarcinoma }\end{array}$ & 0.50 & $(0.22,1.13)$ & .095 & - & - & - & - & - & - & - & - & - \\
\hline NOS vs adenocarcinoma & 0.97 & $(0.59,1.60)$ & .897 & - & - & - & - & - & - & - & - & - \\
\hline Current or former smoker & 2.95 & $(0.69,12.65)$ & .145 & - & - & - & - & - & - & - & - & - \\
\hline Poor performance status & 2.84 & $(1.27,6.32)$ & .011 & - & - & - & - & - & - & - & - & - \\
\hline $\begin{array}{l}\text { Total radiation dose } \\
\text { per 5-Gy increase }\end{array}$ & 0.75 & $(0.63,0.90)$ & .002 & - & - & - & - & - & - & - & - & - \\
\hline
\end{tabular}

RPA resulted in a 2-class risk stratification system, low risk (GTV $<100 \mathrm{~cm}^{3}$ or GTV $\geq 100 \mathrm{~cm}^{3}$ and $\mathrm{FEV}_{1} \geq 80 \%$ ) and high risk (GTV $\geq 100 \mathrm{~cm}^{3}$ and $\left.\mathrm{FEV}_{1}<80 \%\right)$. The 180day survival rates were $93 \%$ for low risk and $79 \%$ for high risk, with an OR of 4.43 (95\% CI: 2.07-9.51; $P<.001$; Cindex: 0.608), adjusted by region, as shown in Figure 1B and Tables 2 and 3. This translated into a 3-fold increase in mortality at 180 days after radiation therapy for high-risk patients $(21 \%)$ compared to low-risk patients $(7 \%)$ and a corresponding difference in OS (log-rank: $P=.007$; 1-year: $73 \%$ vs $55 \%$; 2 -year: $48 \%$ vs $35 \%$; 3 -year: $34 \%$ vs $24 \%$ ). As a sensitivity analysis, Kaplan-Meier estimates were also generated separately for GTV and $\mathrm{FEV}_{1}$ according to RPA generated cut-points, which revealed a significant difference in OS for GTV $(P=.003)$ but not $\operatorname{FEV}_{1}(P=.206)$ (Fig. 1C and D). This was found to be comparable to results shown for 180-day survival based on the same cutpoints as those shown in Table 2 (GTV: $P<.001 ; \mathrm{FEV}_{1}: P=.202$ ). Results from the multivariate logistic regression model incorporating important predictors from RPA $\left(\mathrm{FEV}_{1}, \mathrm{GTV}\right.$, $\mathrm{N}$ stage, and maximum esophagus dose) were used to create a clinical nomogram predictive of 180 -day survival which yielded favorable calibration $\left(\mathrm{R}^{2}=0.947\right)$ as shown in Figure 2A and B.

\section{Discussion}

Concurrent chemoradiation therapy for the treatment of LA-NSCLC has been recommended as a means of increasing survival, but it comes at the cost of increased toxicity. In addition, for a treatment schedule that can take approximately 6 to 8 weeks to deliver, mortality rates in the first 6 to 12 months can be significant. This provided the motivation for the analysis presented here, which aimed to identify factors that might predict early mortality.

The identification of total dose as a significant univariate predictor of 180-day survival and the observed favorable 
Table 3 Actuarial survival estimates for overall survival for all patients $(n=1245)$ and stratified by 180-day survival RPA risk group systems, GTV, FEV 1

\begin{tabular}{|c|c|c|c|c|c|c|c|c|}
\hline Group & $\begin{array}{l}\text { Median } \\
\text { (months) }\end{array}$ & $180 \mathrm{~d}(\%)$ & $1 \mathrm{y}(\%)$ & $1.5 \mathrm{y}(\%)$ & $2 \mathrm{y}(\%)$ & $3 \mathrm{y}(\%)$ & $4 \mathrm{y}(\%)$ & $5 \mathrm{y}(\%)$ \\
\hline All patients & 20.94 & 89.6 & 70.6 & 55.3 & 45.1 & 31.5 & 26.8 & 22.0 \\
\hline \multicolumn{9}{|l|}{ 180-day class 4 RPA risk group system } \\
\hline (Class 1) GTV $<100 \mathrm{~cm} 3+\mathrm{FEV}_{1} \geq 80 \%$ & 30.26 & 94.3 & 78.6 & 65.7 & 54.0 & 47.2 & 37.7 & 33.9 \\
\hline (Class 2) $\mathrm{GTV}<100 \mathrm{~cm}^{3}+\mathrm{FEV}_{1}<80 \%$ & 22.01 & 91.0 & 68.7 & 55.0 & 48.0 & 28.7 & 22.2 & 22.2 \\
\hline (Class 3$) \mathrm{GTV} \geq 100 \mathrm{~cm}^{3}+\mathrm{FEV}_{1} \geq 80 \%$ & 19.29 & 92.7 & 61.8 & 50.3 & 40.5 & 34.1 & 30.7 & 26.3 \\
\hline (Class 4$) \mathrm{GTV} \geq 100 \mathrm{~cm}^{3}+\mathrm{FEV}_{1}<80 \%$ & 12.74 & 79.0 & 54.8 & 42.3 & 35.3 & 23.5 & 23.5 & 11.8 \\
\hline \multicolumn{9}{|l|}{ 180-day class 2 RPA risk group system } \\
\hline \multicolumn{9}{|l|}{ Low risk (at least 1 of) } \\
\hline $\begin{array}{l}\text { (Class 1) GTV }<100 \mathrm{~cm}^{3} \\
\text { (Class } 2) \mathrm{GTV} \geq 100 \mathrm{~cm}^{3}+\mathrm{FEV}_{1} \geq 80 \%\end{array}$ & 22.00 & 92.9 & 72.6 & 59.9 & 47.6 & 34.2 & 28.5 & 22.6 \\
\hline High Risk: GTV $\geq 100 \mathrm{~cm}^{3}+\mathrm{FEV}_{1}<80 \%$ & 12.74 & 79.0 & 54.8 & 42.3 & 35.3 & 23.5 & 23.5 & 11.8 \\
\hline \multicolumn{9}{|l|}{ GTV } \\
\hline$<100 \mathrm{~cm}^{3}$ & 22.64 & 92.9 & 74.2 & 61.4 & 48.7 & 34.3 & 28.3 & 22.3 \\
\hline$\geq 100 \mathrm{~cm}^{3}$ & 15.85 & 85.3 & 61.8 & 44.2 & 36.6 & 26.2 & 24.5 & 19.6 \\
\hline \multicolumn{9}{|l|}{$\mathrm{FEV}_{1}$} \\
\hline$\geq 80 \%$ & 20.81 & 90.5 & 69.3 & 56.6 & 45.4 & 35.3 & 30.5 & 27.2 \\
\hline$<80 \%$ & 20.25 & 86.9 & 65.2 & 51.7 & 45.7 & 31.0 & 24.8 & 21.1 \\
\hline
\end{tabular}

Abbreviations: $\mathrm{d}=$ day; $\mathrm{FEV}_{1}=$ forced expiratory volume in 1 second (defined as the ratio of $\mathrm{FEV}_{1}$ to forced vital capacity [FVC]); GTV $=$ gross tumor volume; RPA = recursive partitioning analysis; $y=$ year.

180-day survival outcomes attributed to higher delivered dose raises a number of important questions given the current uncertainty regarding appropriate dose fractionation. This association appears to become attenuated after performing propensity score matching on pretreatment patient factors, evident from the nonsignificant OS trend favoring intermediate dose ( $>64 \mathrm{~Gy}$ in 32 fractions and $<74$ Gy in 37 fractions) compared to standard dose (6064 Gy in 30-32 fractions; $P=.27$ ) as reported previously (7). Furthermore in the present study, total dose was not identified as an important multivariate predictor of 180-day survival in favor of pulmonary function, tumor volume, $\mathrm{N}$ stage and maximum esophagus dose. Important interactions between total dose, pulmonary function and disease burden may exist, whereby patients with better pulmonary function and lower tumor volumes may be at increased likelihood of receiving higher doses of radiation and vice versa. In contrast, the results of the RTOG protocol 0617, representing the largest protocol to date incorporating modern radiation therapy techniques, associated inferior median and 18-month survival to the 74 Gy dose escalation arm compared to $60 \mathrm{~Gy}$ standard dose arm and have been discussed previously (7-9).

Further examination of the 180-day survival risk stratification system demonstrated a number of important clinical findings. Patients with high-volume tumors $\left(\mathrm{GTV} \geq 100 \mathrm{~cm}^{3}\right)$ combined with high pulmonary function $\left(\mathrm{FEV}_{1} \geq 80 \%\right)$ yielded comparable 180-day and 3- to 5year survival rates to patients with smaller tumors $\left(\right.$ GTV $<100 \mathrm{~cm}^{3}$ ); however, these patients remained at higher risk of mortality between 1 and 2 years after radiation therapy. In contrast, high-risk patients with larger tumors $\left(\mathrm{GTV} \geq 100 \mathrm{~cm}^{3}\right.$ ) and low pulmonary function $\left(\mathrm{FEV}_{1}<80 \%\right)$ showed worse prognosis throughout the entire follow-up period when compared with patients having only one of the criteria (ie, larger tumors or poor pulmonary function). This translated into a three-fold increase of mortality at 180 days after radiation therapy (21\%) compared to low-risk patients (7\%). It is possible that patients with higher pulmonary function may possess a higher tolerance for larger tumors and more aggressive radiation therapy schedules. Additionally, increased disease burden has long been hypothesized to lead to unavoidable increases in lung exposure (ie, lung V20), which in turn can have negative impacts on survival and toxicity. This further suggests that limiting lung toxicity and lung dose as a measure preserve post-treatment residual pulmonary function may help to maximize the prognosis.

Numerous studies have investigated predicting OS in LA-NSCLC and have identified a wide range of tumor and patient-related variables. Tumor size, specifically GTV > 85 to $100 \mathrm{~cm}^{3}$, has been shown to independently predict for survival, consistent with the threshold of $>100 \mathrm{~cm}^{3}$ reported in the current study (10-13). $\mathrm{FEV}_{1}>2 \mathrm{~L}$ has also been reported as a useful prognostic factor, similar to the favorable survival observed for patients with GTV $\geq$ $100 \mathrm{~cm}^{3}$ and $\mathrm{FEV}_{1} \geq 80 \%$ compared to $\mathrm{FEV}_{1}<80 \%$ (14). However, there is debate in published reports as to whether pulmonary function testing provides further improvement in the prediction of survival in the context of LA-NSCLC (15). Performance status has also been shown to be an important prognostic factor for OS, consistent with the results reported in the current study (16). The observed lack of significance for performance status from 


\section{A}

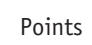

N Stage

GTV (cc)

FEV1 (\%)

Max Esophagus Dose (Gy)

Total Points

180-Day Survival Probability
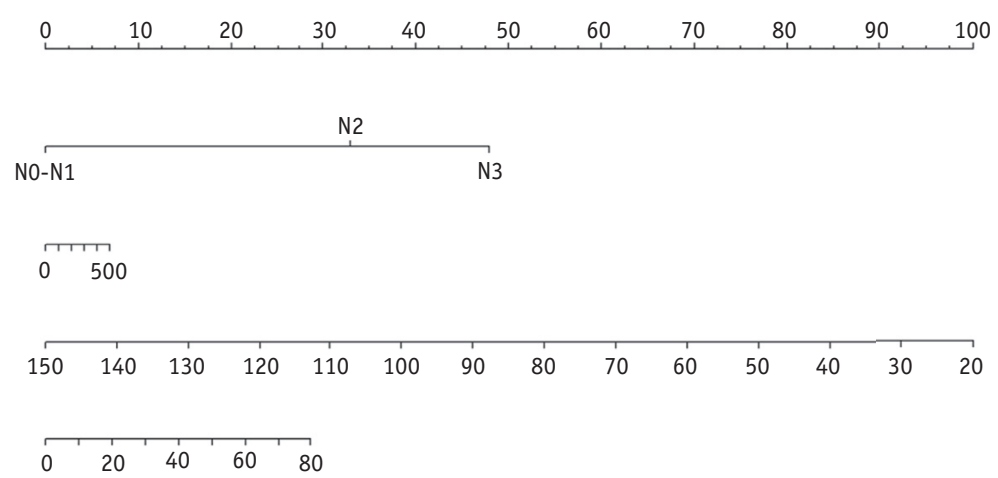

\begin{tabular}{lllllllll}
\hline 0 & 20 & 40 & 60 & 80 & 100 & 120 & 140 & 160
\end{tabular}

$\begin{array}{llllllll}0.99 & 0.975 & 0.95 & 0.9 & 0.8 & 0.7 & 0.6 & 0.5\end{array}$

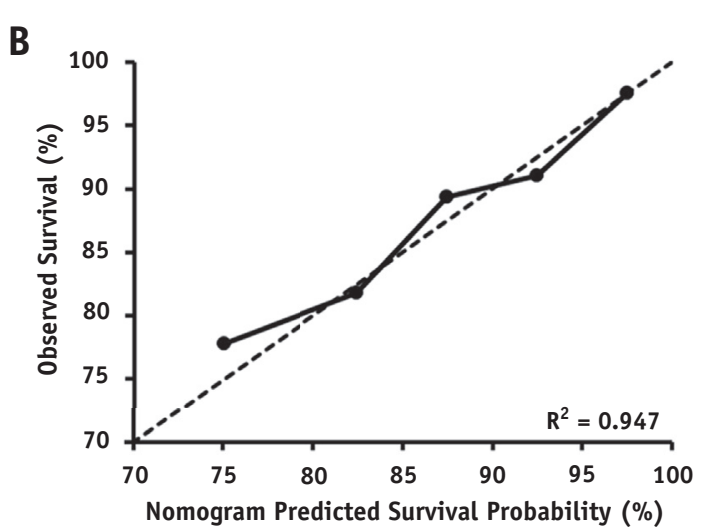

Fig. 2. (A, B) Nomogram predicting 180-day survival and (B) corresponding calibration plot of nomogram-predicted 180day survival probability (\%) versus observed 180-day survival (\%). Abbreviations: FEV1 $=$ forced expiratory volume in 1 second (defined as the ratio of $\mathrm{FEV}_{1}$ to forced vital capacity [FVC]); GTV = gross tumor volume

multivariate analysis in favor of GTV and $\mathrm{FEV}_{1}$ could be partially attributed to the choice of survival endpoint (early mortality vs OS). Other factors have been shown to be clinically useful in the prediction of survival outcomes and include age (17), hemoglobin level (14), smoking status (16), global quality of life (QoL, measured using the European Organisation for Research and Treatment of Cancer Quality of Life Questionnaire C30 [QLQ-C30]) (18), and tumor standardized uptake values of fluorodeoxyglucose-labeled positron-emission tomography (19). Age and smoking status were not found to be significant predictors of survival in the current study, which similarly could be partially attributed to the choice of survival endpoint. It is theoretically possible that if published analyses were reproduced substituting similar early mortality definitions for OS that results could differ in select cases.

The present study has a number of limitations. First, in order to increase statistical power and generalizability for the analyses, patient data from multiple institutions was merged. Inter-institutional variation in data collection procedures, such that not all variables were available from all institutions and patients, may have introduced unknown biases. Second, a substantial proportion of toxicity data is retrospective, and therefore inherently subject to limitations and inaccuracies. Third, heterogeneity in data completeness between and within participating centers is a potential concern. Multivariate analyses and RPA were limited to patients with a complete set of data for all variables under investigation; patients with partial datasets were not included in the final prognostic risk stratification analyses. Additionally, a number of unmeasurable confounders, comorbid factors and additional dosimetric factors (ie, cardiac dosimetry) that were not routinely collected were unavailable to assist in explaining the findings observed in the current study.

In the context of retrospective observational studies, more heterogeneity exists in the delivery of radiation therapy and in patient composition than typically observed in randomized controlled clinical trials, which may be an important contributor to the observed differences in survival outcomes. Furthermore, it is possible that with more complete follow-up data and toxicity reporting, other considerations could be explored, which will be the focus of 
future work. This also highlights the need for prospective validation to further identify whether such associations translate into similar findings when applied to the randomized controlled clinical trial setting. Future work will be focused on external validation of presented clinical prediction tools prior to consideration of clinical implementation.

\section{Conclusions}

Despite these limitations, the current investigation has identified important prognostic factors and proposed a clinical nomogram for early mortality to counsel patients regarding this potentially important negative outcome. Future prospective studies and randomized controlled clinical trials should further explore various approaches to improve the therapeutic ratio in this high-risk patient population. Additionally, the presented associations between poor pulmonary function and larger tumor volumes should be investigated within the context of improved lung dose sparing approaches for con-CRT.

\section{References}

1. Vansteenkiste J, De Ruysscher D, Eberhardt WE, et al. for the ESMO Guidelines Working Group. Early and locally advanced non-small-cell lung cancer (NSCLC): ESMO Clinical Practice Guidelines for diagnosis, treatment and follow-up. Ann Oncol 2013;24(Suppl 6):vi89-vi98.

2. Ramnath N, Dilling TJ, Harris LJ, et al. Treatment of stage III nonsmall cell lung cancer: Diagnosis and management of lung cancer, 3rd ed: American College of Chest Physicians evidence-based clinical practice guidelines. Chest 2013;143(Suppl 5):314S-340S.

3. O'Rourke N, Roqué I, Figuls M, et al. Concurrent chemoradiotherapy in non-small cell lung cancer. Cochrane Database Syst Rev 2010; CD002140.

4. Aupérin A, Le Péchoux C, Rolland E, et al. Meta-analysis of concomitant versus sequential radiochemotherapy in locally advanced non-small-cell lung cancer. J Clin Oncol 2010;28:2181-2190.

5. Palma DA, Senan S, Tsujino K, et al. Predicting radiation pneumonitis after chemoradiation therapy for lung cancer: An international individual patient data meta-analysis. Int J Radiat Oncol Biol Phys 2013; 85:444-450.

6. Palma DA, Senan S, Oberije C, et al. Predicting esophagitis after chemoradiation therapy for non-small cell lung cancer: An individual patient data meta-analysis. Int J Radiat Oncol Biol Phys 2013;87:690-696.
7. Rodrigues G, Senan S, Oberije C, et al. Is intermediate radiation dose escalation with concurrent chemotherapy for stage III non-small cell lung cancer beneficial?: A multi-institutional propensity-score matched analysis. Int J Radiat Oncol Biol Phys 2014;90:S654.

8. Bradley JD, Paulus R, Komaki R, et al. Standard-dose versus highdose conformal radiotherapy with concurrent and consolidation carboplatin plus paclitaxel with or without cetuximab for patients with stage IIIa or IIIb non-small-cell lung cancer (RTOG 0617): A randomized, two-by-two factorial phase 3 study. Lancet Oncol 2015;16: 187-199.

9. Cox JD. Are the results of RTOG 0617 mysterious? Int J Radiat Oncol Biol Phys 2012;82:1042-1044.

10. Zhang J, Gold KA, Lin HY, et al. Relationship between tumor size and survival in non-small cell lung cancer (NSCLC): An analysis of the Surveillance, Epidemiology, and End Results (SEER) registry. J Thorac Oncol 2015;10:682-690.

11. Morgensztern D, Waqar S, Subramanian J, et al. Prognostic significance of tumor size in patients with stage III non-small-cell lung cancer: A surveillance, epidemiology, and end results (SEER) survey from 1998 to 2003. J Thorac Oncol 2012;7:1479-1484.

12. De Petris L, Lax I, Sirzén F, et al. Role of gross tumor volume on outcome and of dose parameters on toxicity of patients undergoing chemoradiotherapy for locally advanced non- small cell lung cancer Med Oncol 2005;22:375-381.

13. Basaki K, Abe Y, Aoki M, et al. Prognostic factors for survival in stage III non-small-cell lung cancer treated with definitive radiation therapy: Impact of tumor volume. Int J Radiat Oncol Biol Phys 2006;64:449454

14. Ademuyiwa FO, Johnson CS, White AS, et al. Prognostic factors in stage III non-small-cell lung cancer. Clin Lung Cancer 2007;8:478482

15. Brunelli A, Charloux A, Bolliger CT, et al. ERS/ESTS clinical guidelines on fitness for radical therapy in lung cancer patients (surgery and chemo-radiotherapy). Eur Respir J 2009;34:17-41.

16. Kawaguchi T, Takada M, Kubo A, et al. Performance status and smoking status are independent favorable prognostic factors for survival in non-small cell lung cancer: A comprehensive analysis of 26,957 patients with NSCLC. J Thorac Oncol 2010;5:620-630.

17. Lara MS, Brunson A, Wun T, et al. Predictors of survival for younger patients less than 50 years of age with non-small cell lung cancer (NSCLC): A California Cancer Registry analysis. Lung Cancer 2014; 85:264-269

18. Movsas B, Moughan J, Sarna L, et al. Quality of life supersedes the classic prognosticators for long-term survival in locally advanced nonsmall-cell lung cancer: An analysis of RTOG 9801. J Clin Oncol 2009; 27:5816-5822.

19. Machtay M, Duan F, Siegel BA, et al. Prediction of survival by (18F) fluorodeoxyglucose positron emission tomography in patients with locally advanced non-small-cell lung cancer undergoing definitive chemoradiation therapy: Results of the ACRIN 6668/RTOG 0235 trial J Clin Oncol 2013:31:3823-3830. 